Dept. of Food Hygiene and Control,

Fac. of Vet. Med., Beni-Suef University

\title{
MICROBIOLOGICAL QUALITY OF COOKING BUTTER IN BENI-SUEF GOVERNORATE
}

\author{
(With 2 Tables)
}

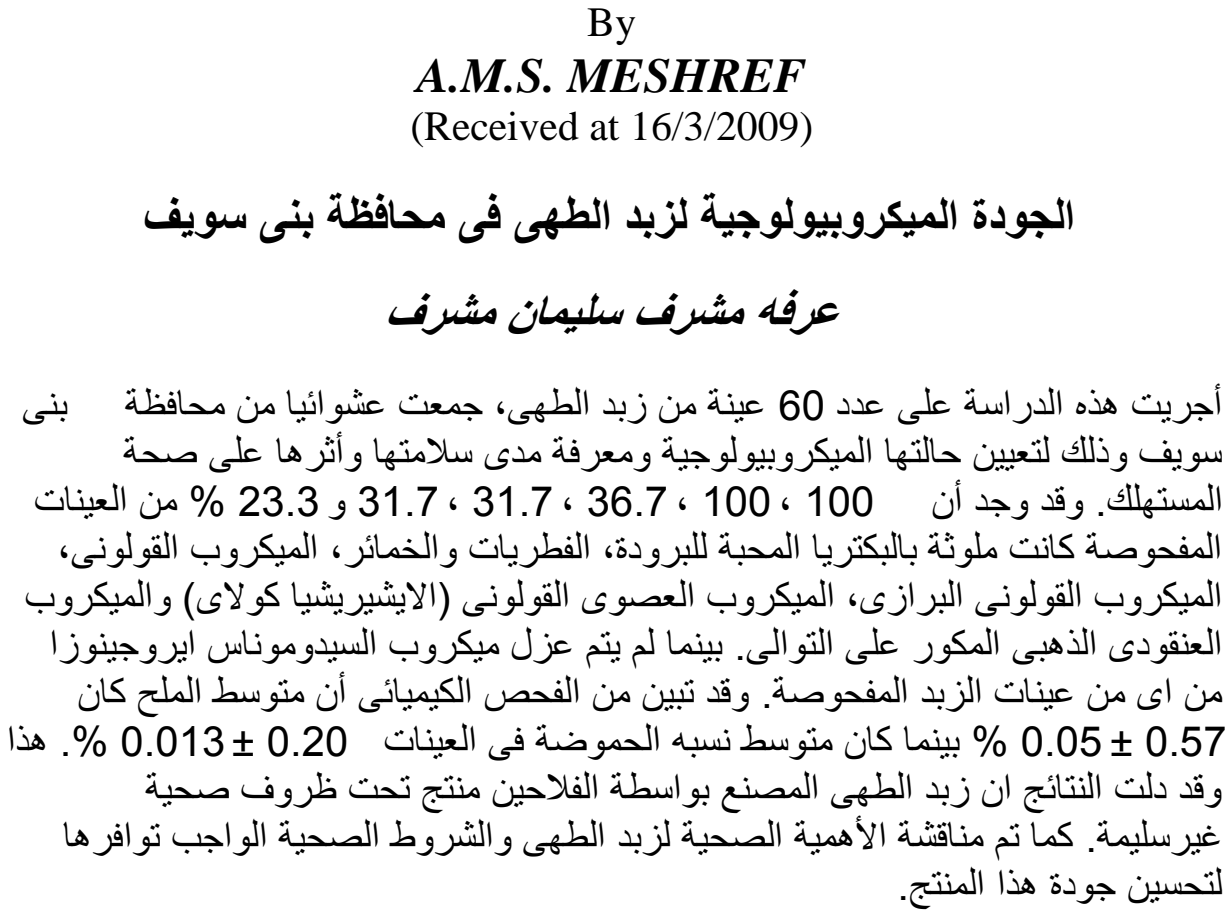

\section{SUMMARY}

A total of 60 random samples of cooking butter, were collected from different farmer's houses in different villages, Beni-Suef Governorate, Egypt. The microbiological examination revealed that 100, 100, 36.7, $31.7,31.7$ and $23.3 \%$ of the examined samples were contaminated by psychrotrophic bacteria, Molds and Yeasts, coliforms, faecal coliforms, E. coli and S. aureus, respectively. None of the examined cooking butter samples contained Ps.aeruginosa. The means values of sodium chloride and titratable acidity were $0.57 \pm 0.05 \%$ and $0.20 \pm 0.013 \%$, respectively. The present study concluded that the cooking butter is produced under unhygienic condition and without good manufacturing practice. The Public health significance and suggestive control measures were discussed. 
Key words: Butter, microorganisms, acidity, sod. chloride

\section{INTRODUCTION}

Cooking butter is one of the most popular types of fat consumed in Egyptian houses. It is produced in villages by rural women that are usually using their traditional knowledge during manufacturing. It is consumed as butter and used as oil for food preparation or for cooking.

Cooking butter is obtained by churning of mechanically separated cream, after storing in skin bag called "Kerba" made from a goat skin. After churning, the butter is manually worked and stored in refrigerators till sold or consumed.

Although the butter is not a highly perishable food, it does undergo spoilage by bacteria and molds. The main source of microorganisms of butter is cream, whether sweet or sour, raw or pasteurized (Jay, 1996). Yeast and molds are important spoilage microorganisms of butter and can result in surface discoloration and offflavor. Psychrotrophic Gram negative bacteria may develop and result proteolytic and lipolytic changes (ICMSF, 2005).

Microbiological analysis of butter for specific pathogens is not considered justified and testing is restricted to potential spoilage microorganisms; together with Escherichia coli and coliform bacteria. (Varnam and Sutherland, 1994).

Likewise, many studies have been carried out in Egypt to evaluate the microbiological quality of cooking butter (Ghoneim, 1963; Khalafalla et al., 1974; Bakheet, 1979; El-Essawy, 1980; Ahmed et al., 1987; Henin and Kaldes, 1992 and El-Kholy, 1994). However, recent information concerning the microbiological quality of cooking butter in Beni-Suef governorate are sketchy or totally absent. Therefore, this work was planned to evaluate the rate of contamination and hygienic quality of cooking butter in Beni-Suef governorate.

\section{MATERIALS and METHODS}

\section{1- Collection of samples:}

A total of 60 random samples of refrigerated cooking butter were aseptically collected from different farmer's houses in different villages, Beni-Suef Governorate, Egypt during winter period (2009). All samples were taken in sterilized bottles and transported under refrigerated condition to the laboratory. Analyses were started without any delay. 


\section{2- Microbiological analyses:}

Samples preparation and serial dilutions were made according to IDF (1992), and then subjected for the following examinations:

a. Psychrotophic colony count was carried out using plate count agar (Difco) after incubation at $7^{\circ} \mathrm{C} \pm 1{ }^{\circ} \mathrm{C}$ for 10 days (Frank et al., 1992).

b. Total coliforms, faecal coliforms and E.coli were estimated by a three tube most probable number (MPN) technique as described by Christen et al. (1992).

c. Enumeration and isolation of S.aureus, was carried out by surface plating technique onto Baird Parker agar (Oxoid) according to technique described by Flowers et al. (1992).

d. Enumeration and isolation of Ps.aeruginosa, was carried out on Cetrimide agar (Biolife) according to technique described by King et al. (1954).

e. Molds and yeasts were enumerated on Sabouraud dextrose agar after incubation at $30^{\circ} \mathrm{C}$ for 3 days (Tantaoui-Elaraki et al., 1983).

\section{3- Sanitary and chemical analyses:}

a- The Titratable acidity (TA) (as lactic acid \%) was measured as method described by Atherton and Newlander (1977).

b- $\mathrm{NaCl}$ concentration was determined using the method described by O'Connor (1995).

\section{4- Statistical analysis:}

SPSS pocket program for windows was used for the statistical analysis. Values of different parameters were expressed as the mean \pm standard error $( \pm$ S.E $)$.

\section{RESULTS and DISCUSSION}

Table 1: Statistical analytical results of different microbial groups/g of examined cooking butter samples.

\begin{tabular}{|l|c|c|c|c|}
\hline Organisms & Min. & Max. & Mean & \pm S.E. \\
\hline Psychrotrophic count & $1 \times 10^{1}$ & $6 \times 10^{5}$ & $3.5 \times 10^{4}$ & $1.3 \times 10^{4}$ \\
\hline Total coliforms & $<3$ & $1.5 \times 10^{4}$ & $8.9 \times 10^{2}$ & $4.05 \times 10^{2}$ \\
\hline Faecal coliforms & $<3$ & $1.5 \times 10^{4}$ & $6.33 \times 10^{2}$ & $3.28 \times 10^{2}$ \\
\hline E.coli & $<3$ & $1.5 \times 10^{4}$ & $3.16 \times 10^{2}$ & $2.52 \times 10^{2}$ \\
\hline S.aureus & $<100^{*}$ & $3 \times 10^{3}$ & $1.55 \times 10^{2}$ & $6.6 \times 10^{1}$ \\
\hline Ps.aeruginosa & $<100^{*}$ & $<100^{*}$ & 0 & 0 \\
\hline Molds \& Yeasts & $4 \times 10^{1}$ & $3 \times 10^{4}$ & $6.3 \times 10^{3}$ & $1.07 \times 10^{3}$ \\
\hline
\end{tabular}

* Not detectable colonies on the plates

Table 2: Frequency distribution of different microbial groups/g of examined cooking butter samples. 


\begin{tabular}{|c|c|c|c|c|c|c|c|c|c|c|c|c|}
\hline \multirow[t]{2}{*}{ Intervals } & \multicolumn{2}{|c|}{$\begin{array}{l}\text { Psychrot- } \\
\text { rophic }\end{array}$} & \multicolumn{2}{|c|}{$\begin{array}{c}\text { Total } \\
\text { coliforms }\end{array}$} & \multicolumn{2}{|c|}{$\begin{array}{c}\text { Faecal } \\
\text { coliforms }\end{array}$} & \multicolumn{2}{|c|}{ E.coli } & \multicolumn{2}{|c|}{ S.aureus } & \multicolumn{2}{|c|}{$\begin{array}{l}\text { Molds } \\
\text { \&Yeasts }\end{array}$} \\
\hline & No & $\%$ & No & $\%$ & $\mathrm{No}$ & $\%$ & No & $\%$ & $\mathrm{No}$ & $\%$ & No & $\%$ \\
\hline$<3$ & - & - & 38 & 63.33 & 41 & 68.3 & 41 & 68.3 & - & - & - & - \\
\hline $3-<10^{1}$ & - & - & 5 & 8.33 & 6 & 10 & 7 & 11.6 & - & - & - & - \\
\hline $10^{1}-<10^{2}$ & 6 & 10 & 7 & 11.67 & 4 & 6.7 & 6 & 10 & 46 & 76.7 & 2 & 3.3 \\
\hline $10^{2}-<10^{3}$ & 18 & 30 & 5 & 8.33 & 5 & 8.3 & 4 & 6.7 & 11 & 18.3 & 12 & 20 \\
\hline $10^{3}-<10^{4}$ & 16 & 26.7 & 3 & 5 & 3 & 5 & 1 & 1.7 & 3 & 5 & 34 & 56.7 \\
\hline $10^{4}-<10^{5}$ & 13 & 21.7 & 2 & 3.33 & 1 & 1.7 & 1 & 1.7 & - & - & 12 & 20 \\
\hline $10^{5}-<10^{6}$ & 7 & 11.6 & - & - & - & - & - & & - & - & - & - \\
\hline Total & 60 & 100 & 60 & 100 & 60 & 100 & 60 & 100 & 60 & 100 & 60 & 100 \\
\hline
\end{tabular}

Table 3: Statistical analytical results of Titratable acidity and $\mathrm{NaCl} \%$ of examined cooking butter samples.

\begin{tabular}{|l|c|c|c|c|}
\hline Test & Min. & Max. & Mean & \pm S.E. \\
\hline Acidity \% & 0.04 & 0.55 & 0.20 & 0.013 \\
\hline $\mathrm{NaCl} \%$ & 0.10 & 1.8 & 0.57 & 0.05 \\
\hline
\end{tabular}

The microflora of butter reflects the quality of cream, the sanitary conditions of equipment used to manufacture the butter and the environmental and sanitary conditions during packaging and handling of such product (Richter et al., 1992).

Results given in Tables $1 \& 2$ show that the psychrotrophic bacteria could be detected in $100 \%$ of the examined cooking butter samples with a mean count of $3.5 \times 10^{4} \pm 1.3 \times 10^{4} \mathrm{cfu} / \mathrm{g}$. In previous studies, nearly similar level of psychotropic counts were reported by Ahmed et al. (1987) and Henin and Kaldes (1992) with mean values of $3.06 \times 10^{4}$ and $3.01 \times 10^{4} \mathrm{cfu} / \mathrm{g}$, respectively. On the contrary, none of the examined cooking butter samples contained detectable level of psychrotrophic bacteria $(<10 / \mathrm{g})$ was reported by El-Sherief (2007).

Psychrotrophic Gram negative bacteria such as Pseudomonas spp. and Flavobacterium spp. may develop and cause off-odour formation and rancidity. Growth of Alteromonas putrefaciens or Flavobacterium malodoris may lead to surface taints very quickly affecting the mass of the product and accompanied by development of a putrid, decomposed or cheesy flavour that render the product unmarketable, leading to economic losses (ICMSF, 2005).

Spoilage of butter may result from the presence of heat resistant proteases and lipases produced by psychrotrophic bacteria during storage of raw milk or cream even after death of spoilage organisms (Kornacki et al., 2001). 
Total coliforms and faecal coliforms were detected in 36.7and $31.7 \%$ of the examined butter samples with mean values of $8.9 \times 10^{2} \pm$ $4.05 \mathrm{x} 10^{2}$ and $6.33 \times 10^{2} \pm 3.28 \times 10^{2}$ cells/g (MPN) respectively (Tables 1\&2).

Many reports dealing with occurrence of coliforms in butter have been accumulated. In those studies, various rates of coliforms were obtained as 35, 67, 82, 77.5, 72, 100 and $66.7 \%$ of examined cooking butter samples by Ghoneim (1963); Bakheet (1979); El-Essawy (1980); Ahmed et al. (1987); Henin and Kaldes (1992); El-Kholy (1994) and Karagozlu and Ergonul (2008), respectively.

According to Egyptian standards (1992), total coliforms and faecal coliforms counts of butter should not exceed the limit 10/g and standards suggested by Robinson (2002) should be < 10 /g, 17 (28.3\%) out of 60 samples were found to be highly contaminated with coliforms, whereas $13(21.7 \%)$ out of 60 samples were found to be highly contaminated with faecal coliforms over this limit. The presence of coliforms in butter is an indicative of poor hygiene and potential risk of food poisoning (Wilbey, 2002).

E. coli is an indicator of faecal contamination and the possibility of the presence of enteric pathogens. E.coli was found in 19 (31.7\%) out of 60 examined cooking butter samples. Moreover, the mean count of E.coli was $3.16 \times 10^{2} \pm 2.52 \times 10^{2}$ organisms/g (MPN) (Tables 1\&2). On the contrary, higher incidence rates were reported by Ahmed et al. (1987); Henin and Kaldes (1992) and Karagozlu and Ergonul (2008) as they found 55, 56 and $64.4 \%$ of the samples were contaminated with E. coli, respectively. All positive samples do not comply with both Egyptian standards and standards suggested by Robinson (2002), since both recommended the freedom of $1 \mathrm{~g}$ of butter from E.coli.

In the present study, 14 samples yielded $S$. aureus ranging from $10^{2}$ to $3 \times 10^{3} \mathrm{cfu} / \mathrm{g}$ and 23.3 . \% of the samples do not comply with the Egyptian standards and standard suggested by Robinson (2002) of freedom of $1 \mathrm{~g}$ of butter from S.aureus (Tables 1\&2). The detection rate of S.aureus was not in agreement with the result of Karagozlu and Ergonul (2008) who reported no S.aureus in their butter samples. The presence of $S$. aureus in cooking butter may be from an endogenous source, i.e. using raw cream for manufacture of butter or from an exogenous source, i.e. a result of handling and inadequate personnel hygiene of farmer's wife.

Neither the absence of S.aureus nor the presence of small numbers of organism can provide complete assurance that the butter is 
safe, since conditions inimical to the survival of $S$. aureus may result in a diminished population or death of viable microbial cells, while sufficient toxins remains to elicit symptoms of staphylococcal food poisoning (Bennett and Monday, 2003).

None of the examined cooking butter samples contained Ps.aeruginosa (Table 1). This finding is completely in agreement with those of Nasr et al. (1992), who stated that this may be due to the effect of high acidity and salt content.

It could be seen from Tables $1 \& 2$ that $100 \%$ of the examined cooking butter samples contained Molds and Yeasts with a mean count of $6.3 \times 10^{3} \pm 1.07 \times 10^{3} \mathrm{cfu} / \mathrm{g}$. The examined butter is considered having unacceptable hygienic quality, since all of the examined samples were above the limit of $<10 \mathrm{cfu} / \mathrm{g}$. suggested by Robinson (2002).

Many reports are dealing with the occurrence of molds and yeasts in butter. In those studies, various rates of molds and yeasts were reported as 9.4, 50 and $92.7 \%$ of the examined butter samples by Hankin and Hanna (1984); Paula et al. (1989) and Con (1990), respectively. Recent studies found that $56 \& 84 \%$ and $75 \& 85 \%$ of examined cooking butter samples were contaminated with molds and yeasts (Bahout, 2001 and El-Diasty and Salem, 2009), respectively. Several previous studies recorded higher levels of molds and yeasts contamination in butter as $5.3 \times 10^{4}, 2.7 \times 10^{4}, 7.11 \times 10^{4}$ and $6.99 \times 10^{4}$ by Ozalp et al. (1978); Ozdemir (1986); Ahmed et al. (1987) and Henin and Kaldes (1992), respectively.

The presence of molds and yeasts in butter are objectionable as they grow at a wide range of temperature and $\mathrm{pH}$ values resulting surface discolouration and off-flavour (ICMSF, 2005). Molds contamination not only cause deterioration of the foods but also adversely affect the health of humans and animals, since they produce toxic metabolites called mycotoxins (Ismail and Sabreen, 2001).

Generally, the microbial contamination of butter could be attributed to the fact that it is usually made from raw cream, in addition to the primitive way of processing, handling, storage and marketing.

On the other hand, Table 3 showed that the mean values of Titratable acidity (TA) and $\mathrm{NaCl} \%$ were $0.20 \pm 0.013$ and $0.57 \pm 0.05 \%$, respectively. Similar TA was reported in earlier study on cooking butter by El-Kholy (1994). On the contrary, higher mean values of TA were showed by Sagdic et al. (2002) and Mourad and NourEddine (2006). 
The mean $\mathrm{NaCl} \%$ in the present study was nearly similar to those reported by Sagdic et al. (2002) and lower than those recorded by El-Sadek et al. (1975); Hayaloglu (1999) and Mourad and Nour-Eddine (2006). While, El-Kholy (1994) and Samet-Bali et al. (2009) noted lower mean values than in this study.

According to the Egyptian Standards, all of the samples were in comply with the limit not exceed $2 \%$ salt. Butter usually contains $1.5-2 \% \mathrm{NaCl}$ will contain 9- $12.5 \%$ in the aqueous phase, a concentration strongly inhibitory to most microorganisms. On the other hand, lactic acid level produced as a result of natural souring during storage of cream in Kerba may be sufficiently high to exert an inhibitory effect (Varnam and Sutherland, 1994 and Kornacki et al., 2001). Likewise, Minor and Marth (1972) reported that S. aureus was able to grow in butter with $0-1 \%$ salt. This can conclude that the role of $\mathrm{NaCl} \%$ $(0.57 \%)$ in this study on controlling the microbial growth in cooking butter may be questionable and the probability of growth of pathogenic microorganisms like $S$. aureus is high.

In conclusion, the current investigation has indicated that butter is produced under unhygienic condition at Beni-Suef governorate. The counts of microorganisms above the recommended criteria and the presence of pathogenic bacteria may pose a risk for public health. Therefore, there is a necessity for developing the hygienic status of locally produced butter through provision of information to rural women on good process hygiene and to consumers on how to handle their foods including correct storage to protect them from infection and to save a lot of products from being deteriorated. Also, butter should not be manufactured from raw cream or, if it is, it should be used only for cooking where it will receive adequate heat treatment.

\section{REFERENCES}

Ahmed, A.A-H.; Moustafa, M.K. and Abdel-Hakiem, E.H. (1987): Sanitary condition of cooking butter manufactured in Assiut city. Assiut Vet. Med. J., 17:37, 79-86.

Atherton, H.V. and Newlander, J.A. (1977): Chemistry and testing of dairy products. $4^{\text {th }}$ edition, AVI publishing company, Inc. USA.

Bahout, A.A. (2001): Occurrence of fungi in butter sold in Sharkia province. $1^{\text {st }}$ Cong. Of Food Hygiene \& human Health, 6-8 Feb., Fac.Vet. Med., Assiut Univ., Egypt. 
Bakheet, I.S. (1979): Microbiological studies on Egyptian market butter with special reference to enteric pathogens and food poisoning microorganisms. Ph.D. Thesis, Fac. Vet. Med., Zagazig Univ., Egypt.

Bennett, R.W. and Monday, S. (2003): Staphylococcus aureus. In: International handbook of foodborne pathogens. Marcel Dekker, Inc., New York.

Christen, G.L.; Davidson, P.M.; McAllister, J.S. and Roth, L.A. (1992): Coliform and other indicator bacteria. in R.T. Marshall (ed.), Standard methods for the examination of dairy products. American Public Health Association, Washington, D.C.

Con, A.H. (1990): Samsun piyasasmda satisa sunulan tereyaglarinin bazi nitelikleri uzerine bir arastirma. (A research on several characteristics of butter sold in Samsun markets). Ondokuz Mayis University Applied and Natural Sciences Institute Samsun.

Egyptian Standards. (1992): Milk and dairy products: Natural cow 's and buffalo's butter. Egyptian Organization for Standardization and Quality Control.

El-Diasty, E.M. and Salem, R.M. (2009): Incidence of lipolytic and proteolytic fungi in some milk products and their public health significance. Arab J. Biotech., 12: 1, 49-56.

El-Essawy, H.A. (1980): Public health importance of Enterobacteriaceae and Enterococci in some dairy products. Ph.D. Thesis, Fac.Vet. Med., Cairo Univ.

El-Kholy, A.M. (1994): Enterobacteriaceae as index of sanitary quality for local and imported butter. $6^{\text {th }}$ Sci.Cong. 20-22 Nov., Fac.Vet. Med., Assiut Univ.8-13, Egypt.

El-Sadek, G.M.; Teama, Z.Y.; Khalafalla, S.M. and Sultan, N.F. (1975): Compositional properties of market butter in Egypt. Milchwissenshatt, 30, 354-356.

El-Sherief, K.A. (2007): Incidence, Economic and public health significance of Pseudomonas species in milk and some dairy products. M.V.Sc. Thesis, Fac.Vet.Med., Beni-Suef Univ., Egypt.

Flowers, R.S.; Andrews, W.; Donnelly, C.W. and Koenig, E. (1992): Pathogens in milk and milk products. in R.T. Marshall (ed.), Standard methods for the examination of dairy products. American Public Health Association, Washington, D.C. 
Frank, J.F.; Christen, G.L. and Bullerman, L.B. (1992): Tests for groups of microorganisms. In R.T. Marshall (ed.), Standard methods for the examination of dairy products. American Public Health Association, Washington, D.C.

Ghoneim, N. (1963): Studies on the microflora of Damietta cheese and locally made butter. M.V.Sc. Thesis, Fac. Vet. Med., Cairo Univ.

Hankin, L. and Hanna, J.G. (1984): Quality of butter and blends of butter with oleomargarine. Dairy Sci., 46:6, 3816. (cited after Karagozlu and Ergonul, 2008).

Hayaloglu, A.A. (1999): A comparative study on physicochemical, microbiological and organoleptic qualities of butter produced from cream and yoghurt in Malatya region. M.Sc. Thesis, p.74, Cukurova Univ., Institute of natural and applied sciences, Adana, Turkey. (cited after Samet-Bali et al., 2009).

Henin, A.Y. and Kaldes, Y.T. (1992): Microbiological evaluation of cooking butter manufactured in Minia Governorate. Beni-Suef Vet. Med. J., 2:2, 291-297.

ICMSF. (2005): Microrganisms in Foods. Microbial Ecology of food commodities. Chap 11: Oil and Fat based foods. pp. 480-521. $2^{\text {nd }}$ edition, Kluwer Academic/ Plenum Publishers, New York.

IDF. (1992): Milk and milk products. Preparation of samples and dilutions microbiological examination .Brussels. Belgium.

Ismail, M.A. and Sabreen, M.S. (2001): Associated mycobiota of some types of cheese and cooking butter. Assiut Vet. Med. J., 44: 88, 176-197.

Jay, M.J. (1996): Modern food microbiology. $5^{\text {th }}$ edition, Chapman and Hall publisher, USA.

Karagozlu, N. and Ergonul, B. (2008): Microbiological attributes of Turkish butters sold under markets conditions. J. Verbr. Lebensm., 3, 376-379.

Khalafalla, S.M.; El-Sadek, G.M.; Teama, Z.Y. and Sultan, N.E. (1974):

Microbiological studies on market butter in Egypt. Egyptian J.

Dairy Sci. 2 (2): 119-126.

King, E.O.; Ward, M.K. and Raney, D.E. (1954): Two simple media for the demonstration of pyocyanin and fluorescein. J. of Laboratory and Clinical Medicine, 44:, 301-307.

Kornacki, J.L.; Flowers, R.S. and Bradley, Jr. R.L. (2001): Microbiology of butter and related products. In applied dairy 
microbiology, $2^{\text {nd }}$ edition, edited by Marth, E.H. and Steele, J.L., by Marcel Dekker, Inc., USA.

Minor, T.E. and Marth, E.H. (1972): Staphylococcus aureus and enterotoxin A in cream and butter. J. Dairy Sci., 55:1410-1414.

Mourad, K. and Nour-Eddine, K. (2006): Physicochemical and microbiological study of shmen, a traditional butter made from milk in the sahara (Algeria): isolation and identification of lactic acid bacteria and yeasts. GRASAS Y ACEITES, 57:2, 198-204.

Nasr, S.; Ahmed, A-H.A.; Saad, N.M. and Korashy, E. (1992): Incidence of Pseudomonas aeruginosa in milk and some milk products. $5^{\text {th }}$ Sci. Cong., Fac. Vet. Med., Assiut Univ., 8-10 Nov., 125131.

O' Connor, C.B. (1995): Rural dairy technology: ILRI (International Livestock Research Institute) Training Manual 1, Addis Ababa, Ethiopia.

Ozalp, E.; Tekinsen, O.C. and Ozalp, G. (1978): Turk tereyaglarinin mikrobiyolojik kaliteleri uzerinde arastirma (A research on microbiological quality of Turkish butter). Ankara Univ., J.Vet. Fac., 25: 467-479.

Ozdemir, S. (1986): Isolation and identification of coliform bacteria from fresh white cheese and breakfast butter. Ataturk Univ., Applied and Natural Science Institute, Department of Agricultural product technology.

Paula, C.R.; Gambale, S.T.; Laria, S.A. and Filho, R. (1989): Occurrence of fungi in butter available for public health consumption in the city of Sao Paulo. Dairy Sci., 51:5, 2090. (cited after Karagozlu and Ergonul, 2008).

Richter, R.L.; Ledford, R.A. and Murphy, S.C. (1992): In Compandium of Methods for the Microbiological examination of foods, American Public Health Association. Washington, D.C., 1992. Chap. 45, pp. 837-856.

Robinson, R.K. (2002): Dairy Microbiology Handbook, the microbiology of milk and milk products. $3^{\text {rd }}$ edition, John Wiley and Sons, Inc., New York.

Sagdic, O.; Arici, M. and Simsek, O. (2002): Selection of starters for a traditional Turkish yayik butter made from yoghurt. Food Microbiol., 19: 303-312.

Samet-Bali, O.; Ayadi, M.A. and Attia, H. (2009): Traditional Tunisian butter: Physicochemical and microbial characteristics and 
storage stability of the oil fraction. Food Science and Technology, 42: 899-905.

Tantaoui-Elaraki, A.; Berrada, M.; El-Marrakchi, A. and Berramou, A. (1983): Etude sur le Lben marocain. Lait, 63, 230-245.

Varnam, A.H. and Sutherland, J.P. (1994): Milk and milk products. $1^{\text {st }}$ edition, Chapman and Hall publisher, London.

Wilbey, R.A. (2002): Microbiology of cream and butter. In: Dairy Microbiology Handbook, the microbiology of milk and milk products. Robinson, R.K. $3^{\text {rd }}$ edition, John Wiley and Sons, Inc., New York. 